\title{
Antiplasmodial activity of iron(II) and ruthenium(II) organometallic complexes against Plasmodium falciparum blood parasites
}

\author{
Nicolli Bellotti de Souza', Anna Caroline Campos Aguiarr', Alane Cabral de Oliveira ${ }^{2,3}$, Siden Top ${ }^{4}$, \\ Pascal Pigeon $^{4,5}$, Gérard Jaouen ${ }^{4,5}$, Marilia Oliveira Fonseca Goulart ${ }^{2}$, Antoniana Ursine Krettlii+ \\ ${ }^{1}$ Fundação Oswaldo Cruz, Centro de Pesquisas René Rachou, Belo Horizonte, MG, Brasil ${ }^{2}$ Universidade Federal de Alagoas, \\ Instituto de Química e Biotecnologia, Maceió, AL, Brasil ' ${ }^{3}$ Universidade Federal de Alagoas, Faculdade de Nutrição, Maceió, AL, Brasil \\ ${ }^{4}$ Sorbonne Universités, Université Pierre-et-Marie-Curie, Unités Mixtes de Recherche 8232, Paris, France \\ ${ }^{5}$ Ecole Nationale Supérieure de Chimie de Paris, Paris, France
}

This work reports the in vitro activity against Plasmodium falciparum blood forms (W2 clone, chloroquine-resistant) of tamoxifen-based compounds and their ferrocenyl (ferrocifens) and ruthenocenyl (ruthenocifens) derivatives, as well as their cytotoxicity against HepG2 human hepatoma cells. Surprisingly with these series, results indicate that the biological activity of ruthenocifens is better than that of ferrocifens and other tamoxifen-like compounds. The synthesis of a new metal-based compound is also described. It was shown, for the first time, that ruthenocifens are good antiplasmodial prototypes. Further studies will be conducted aiming at a better understanding of their mechanism of action and at obtaining new compounds with better therapeutic profile.

Key words: Plasmodium falciparum - metallodrug activity - ruthenocifens - ferrocifens

Malaria is estimated to have threatened 198 million people in 2013 (WHO 2014). Resistance of Plasmodium falciparum to artemisinin derivatives (Miotto et al. 2013, Ashley et al. 2014) and of Plasmodium vivax to chloroquine (CQ) (Graf et al. 2012, Marques et al. 2014) hinders chemotherapy-based efforts to control the disease. P. falciparum causes the most deadly form of the disease (WHO 2014), thus new antimalarial drugs are needed, especially towards CQ-resistant parasites.

The potentiality of the metal-based approach to discover new drugs has been highlighted by ferroquine, which proceeded to Phase IIB clinical trials as an antimalarial drug (Biot 2004, Biot et al. 2012a, Held et al. 2015b). Very recently, the combination of ferroquine with artesunate was shown to be safe at all doses tested, associated with high cure rates. Therefore it represents a promising alternative for drug combination against $P$. falciparum malaria (Held et al. 2015b). Ferroquine is the only candidate in Phase II clinical trials that has a halflife longer than 20 days, allowing for a prolonged posttreatment prophylactic effect and diversifying the antimalarial portfolio (Held et al. 2015a). Experimentally, two other ferrocene derivatives have shown important antiplasmodial activity (Soares et al. 2010).

doi: 10.1590/0074-02760150163

Financial support: CNPq/FAPEMIG, FAPEAL/CNPq, CAPES, MS, CNPq, MCT/CNPq/CT-Saúde/MS/SCTIE/DECIT (PRON-

EX-55675/2009-2, Doenças Negligenciadas-404455/2012-3), FAPEMIG (PRONEX- 16712), ANR (ANR-10-BLAN-706; Mecaferrol)

AUK, NBS and MOFG receive fellowship from CNPq and CAPES.

+Corresponding author: akrettli@cpqrr.fiocruz.br

Received 28 April 2015

Accepted 14 October 2015
The ruthenium $(\mathrm{Ru})$-based compounds also attract interest due to their biological activities as anticancer (Pizarro et al. 2010), antibacterial (Wenzel et al. 2013), leishmanicidal, trypanosomicidal (Martínez et al. 2012), antiplasmodial (Biot et al. 2007, Glans et al. 2012), including Ru-CQ complexes (Martínez et al. 2009, Rajapakse et al. 2009). Ruthenocenyl compounds were also described as bioprobes of ferroquine, used in an attempt to elucidate its molecular mechanism of action (Biot et al. 2012b). The use of Ru allowed to evercome the difficulty of detecting iron (Fe)-based compounds among the numerous $\mathrm{Fe}$-containing components of the parasite digestive vacuole (DV) (Dubar et al. 2011, 2012).

An enhanced antiplasmodial activity has been obtained by complexation with $\mathrm{Ru}$ in relation to the free ligands, providing molecules such as Ru-lapachol complexes (Barbosa et al. 2014) and Ru-pyridil ester (Chellan et al. 2014), or ether complexes (Chellan et al. 2013), as well as thiosemicarbazone Ru-arene complexes (Adams et al. 2013). Another example of successful complexation of Ru with an antifungal agent (clotrimazole) has led to antiparasitic compounds over 50 -fold more potent in relation to the parental compounds (Martínez et al. 2012). Furthermore, the substitution of Fe by Ru in ferroquine led to higher anti-P. falciparum activity against $\mathrm{K} 1$ strain, another resistant parasite strain (Beagley et al. 2003).

Several ferrocenyl derivatives of tamoxifen demonstrate antiproliferative activity against breast cancer cells (Tan et al. 2012, Cázares-Marinero et al. 2014, de Oliveira et al. 2014).

The present paper reports the evaluation of tamoxifen-based compounds and their ferrocene and ruthenocene derivatives, designed as ferrocifens and ruthenocifens for: (i) antiplasmodial activity against $P$. falciparum (W2 clone, CQ-resistant) blood parasites in culture, and (ii) cytotoxicity in vitro against HepG2 human hepatoma cells. This is the first report dealing with ruthenocifens 
as antiplasmodial compounds. The synthesis of a new ferrocenophane is also described.

\section{MATERIALS AND METHODS}

Compounds 1, 2, 3, 4, 5, 6, 7, 9, 10, 11, 12, and 13 were prepared according to literature procedures (references are given in Table I). The synthesis of compounds 8 is described in the present paper. Tetrahydrofuran (THF) was distilled over sodium/benzophenone prior to use. Thin layer chromatography was performed on silica gel $60 \mathrm{GF}_{254} \cdot{ }^{1} \mathrm{H}$ and ${ }^{13} \mathrm{C}$-NMR spectra were acquired on a Bruker $300 \mathrm{MHz}$ spectrometer. Mass spectrometry was carried out at the Mass Spectrometry Service at National Chemical Engineering Institute, Paris. High resolution mass spectra (HRMS) were acquired in the Paris Institute of Molecular Chemistry (Mixed Research Unit 8232) at the Pierre and Marie Curie University, Paris.

Measurement of lipophilicity data - Measurements of the octanol/water partition coefficient $\left(\log P_{\mathrm{o} / \mathrm{w}}\right)$ were made by the HPLC technique according to a method described previously (Minick et al. 1988, Pomper et al. 1990). Measurement of the chromatographic capacity factors $(k)$ for each molecule was done at various concentrations in the range of $95-75 \%$ methanol containing $0.25 \%(\mathrm{v} / \mathrm{v}) 1-\mathrm{octanol}$, and an aqueous phase consisting of $0.15 \%(\mathrm{v} / \mathrm{v}) \mathrm{n}$-decylamine in the buffering agent 3-morpholinopropane-1-sulfonic acid (MOPS) prepared in 1-octanol saturated water adjusted to $\mathrm{pH} 7.4$. These capacity factors $\left(k^{\prime}\right)$ are extrapolated to $100 \%$ of the aqueous component given the value of $k^{\prime}$. The $\log P_{\text {, }}$ is obtained by the formula $\log P_{\mathrm{o} / \mathrm{w}}=0.13418+0.9845^{\mathrm{o} / \mathrm{W}} \log k^{\prime}$.

Synthesis of 1-[(4-(3-dimethylaminopropoxy)phenylphenyl)methylidene][3]ferrocenophane, 8 - Titanium chloride (10.04 g, $5.8 \mathrm{~mL}, 52.9 \mathrm{mmol})$ was added dropwise to a suspension of zinc powder $(4.84 \mathrm{~g}, 74 \mathrm{mmol})$ in dry THF $(400 \mathrm{~mL})$ at $10-20^{\circ} \mathrm{C}$. The mixture was heated at reflux for $2 \mathrm{~h}$. A second solution was prepared by dissolving [3] ferrocenophan-1-one (2.54 g, $10.6 \mathrm{mmol})$ and 4-(3-dimethylaminopropoxy)benzophenone (3 g, $10.6 \mathrm{mmol})$ in dry THF $(25 \mathrm{~mL})$. This latter solution was added, dropwise, to the first solution and then the reflux was continued for $4 \mathrm{~h}$. After cooling to room temperature, the mixture was stirred with water and dichloromethane. The mixture was acidified with diluted hydrochloric acid until dark colour disappeared, then, sodium hydrogenocarbonate was added to maintain a $\mathrm{pH}$ close to neutral and the mixture was decanted. The aqueous layer was extracted with dichloromethane and the combination of organic layers was dried on magnesium sulphate. After concentration under reduced pressure, the crude product was chromatographed on silica gel column with acetone as the eluent, then was purified by semi-preparative HPLC [Shimadzu apparatus with a Nucleodur C18 column $(1=25 \mathrm{~cm}, 1=3.2 \mathrm{~cm}$, particle size $=10 \mathrm{~mm}]$ with a solution of methanol/triethylamine $95 / 5$, as the eluent, giving an undetermined $2 / 1$ ratio of $Z$ and $E$ isomers. Compound 8 (yield of $84 \%$ ) was re-crystallised from diethyl ether and was obtained as a bright yellow product as an undetermined 4/1 ratio of $E$ and $Z$ isomers. ${ }^{~} \mathrm{H}$ NMR $\left(\mathrm{CDCl}_{3}, 300 \mathrm{MHz}\right): \delta$
1.82-2.04 (m, $\left.2 \mathrm{H}, \mathrm{CH}_{2}\right), 2.23$ and $2.27\left(\mathrm{~s}, 6 \mathrm{H}, \mathrm{NMe}_{2}\right)$, 2.31-2.53 (m, 4H, $\mathrm{CH}_{2} \mathrm{~N}+\mathrm{CH}_{2}$ cycle), 2.60-2.68 and 2.68-2.75 (m, 2H, $\mathrm{CH}_{2}$ cycle), 3.90 (t, $J=6.4 \mathrm{~Hz}, 2 \mathrm{H}$, $\mathrm{CH}_{2} \mathrm{O}$ major isomer), 3.94-4.07 (m, $10 \mathrm{H}, \mathrm{CH}_{2} \mathrm{O}$ minor isomer $+\mathrm{C}_{5} \mathrm{H}_{4}$ major and minor isomers), 4.21 (t, $J=1.8$ $\mathrm{Hz}, 2 \mathrm{H}, \mathrm{C}_{5} \mathrm{H}_{4}$ major isomer), 6.61 and $6.88(\mathrm{~d}, J=8.8 \mathrm{~Hz}$, $\left.2 \mathrm{H}, \mathrm{C}_{6} \mathrm{H}_{4}\right), 6.94$ and $7.14\left(\mathrm{~d}, J=8.8 \mathrm{~Hz}, 2 \mathrm{H}, \mathrm{C}_{6} \mathrm{H}_{4}\right), 7.02-$ $7.10\left(\mathrm{~m}, 1 \mathrm{H}, \mathrm{C}_{6} \mathrm{H}_{5}\right), 7.20-7.39\left(\mathrm{~m}, 4 \mathrm{H}, \mathrm{C}_{6} \mathrm{H}_{5}\right) .{ }^{13} \mathrm{C}$ NMR $\left(\mathrm{CDCl}_{3}, 75.4 \mathrm{MHz}\right): \delta 27.4$ and $27.5\left(\mathrm{CH}_{2}\right), 28.7\left(\mathrm{CH}_{2}\right)$, $40.9\left(\mathrm{CH}_{2}\right), 45.3\left(2 \mathrm{CH}_{3} \mathrm{NMe}_{2}\right), 56.4\left(\mathrm{CH}_{2}\right), 65.9$ and 66.1 $\left(\mathrm{CH}_{2} \mathrm{O}\right), 68.2\left(2 \mathrm{CH} \mathrm{C} \mathrm{C}_{5} \mathrm{H}_{4}\right), 68.5$ and $68.7\left(2 \mathrm{CH} \mathrm{C}_{5} \mathrm{H}_{4}\right)$, $70.2^{2}\left(2 \mathrm{CH} \mathrm{C}_{5} \mathrm{H}_{4}\right), 70.3\left(2 \mathrm{CH} \mathrm{C} \mathrm{C}_{5} \mathrm{H}_{4}\right), 83.7\left(\mathrm{C}_{\mathrm{ip}}\right), 86.7$ and $86.8\left(\mathrm{C}_{\mathrm{in}}\right), 113.2$ and $114.0\left(2 \mathrm{CH} \mathrm{C}_{6} \mathrm{H}_{4}\right), 125.9$ and 126.6 $\left(\mathrm{CH} \mathrm{C} \mathrm{CH}_{5}\right), 127.2$ and $128.1\left(2 \mathrm{CH}_{\text {arom }}\right), 129.3$ and 130.4 $\left(2 \mathrm{CH}_{\text {arom }}\right), 130.6$ and $131.6\left(2 \mathrm{CH}_{\text {arom }}\right), 133.6$ and 134.3 (C), 135.5 and 135.9 (C), 140.5 and 140.6 (C), 143.4 and 143.8 (C), 157.1 and 157.7 (C). MS (EI, $70 \mathrm{eV}) \mathrm{m} / \mathrm{z}$ : 491 $[\mathrm{M}]^{+}, 405\left[\mathrm{M}-\mathrm{NMe}_{2} \mathrm{CH}_{2} \mathrm{CH}_{2}\right]^{+}, 86\left[\mathrm{NMe}_{2} \mathrm{CH}_{2} \mathrm{CH}_{2}\right]^{+}, 58$ $\left[\mathrm{NMe}_{2} \mathrm{CH}_{2}\right]^{+}$. HRMS (ESI, $\mathrm{C}_{31} \mathrm{H}_{34} \mathrm{FeNO}:[\mathrm{M}+\mathrm{H}]^{+}$) calculated: 492.1990 , found: 492.1998.

Cytotoxicity tests with HepG2 human hepatoma cells and monkey kidney (BGM) cell lines - Cytotoxicity tests were performed with HepG2 human hepatoma cells or normal BGM cell lines using 3-(4,5-dimethylthiazol-2-yl)-2,5 diphenyltetrazolium bromide (Molecular Probes, USA) (Denizot \& Lang 1986) or neutral red (Borenfreund et al. 1987) methods. The minimum lethal dose for $50 \%$ of the cells $\left(\mathrm{MLD}_{50}\right)$ was determined (de Madureira et al. 2002) by a curve-fitting software (Microcal Origin Software v.5.0; Origin Lab Co, USA) and further used to calculate the selectivity index (SI) of the active compounds [SI $=\mathrm{MDL}_{50}$ inhibitory concentration for $\left.50 \%\left(\mathrm{IC}_{50}\right)\right]$ (Bézivin et al. 2003). The SI was calculated in order to give an insight into the therapeutic index of the molecules, i.e., how far the toxic concentration is from the therapeutic one. Molecules having $\mathrm{MLD}_{50}>500 \mu \mathrm{M}$ were considered not toxic, if between $500-100 \mu \mathrm{M}$ moderately toxic, and those having $\mathrm{MLD}_{50}<100 \mu \mathrm{M}$ were considered toxic. Molecules with $\mathrm{SI} \leq 10$ were also considered toxic.

Continuous culture of $P$. falciparum and in vitro tests of drug activity - Blood-stage $P$. falciparum parasites, W2 clone CQ-resistant (Oduola et al. 1988), maintained according to Trager \& Jensen (1976), were used in the drug activity tests after sorbitol-synchronisation (Lambros \& Vanderberg 1979). The antiplasmodial activity of the compounds was determined relative to control parasites kept in culture medium only (Rieckmann et al. 1978) through the anti-histidine-rich protein II assay (Noedl et al. 2002). The $\mathrm{IC}_{50}$ of parasite growth was determined through sigmoidal dose-response curves built by curve-fitting software (Microcal Origin Software v.5.0). Compounds exhibiting $\mathrm{IC}_{50}$ values lower than $6 \mu \mathrm{M}$ were considered active, those with $\mathrm{IC}_{50}$ between $20-60 \mu \mathrm{M}$ partially active, and those higher than $60 \mu \mathrm{M}$, inactive.

\section{RESULTS}

The compounds evaluated in this work belong to five structural classes and their reported biological activities and some physicochemical parameters are listed in Table I. They are classified as: organic tamoxifen-like com- 


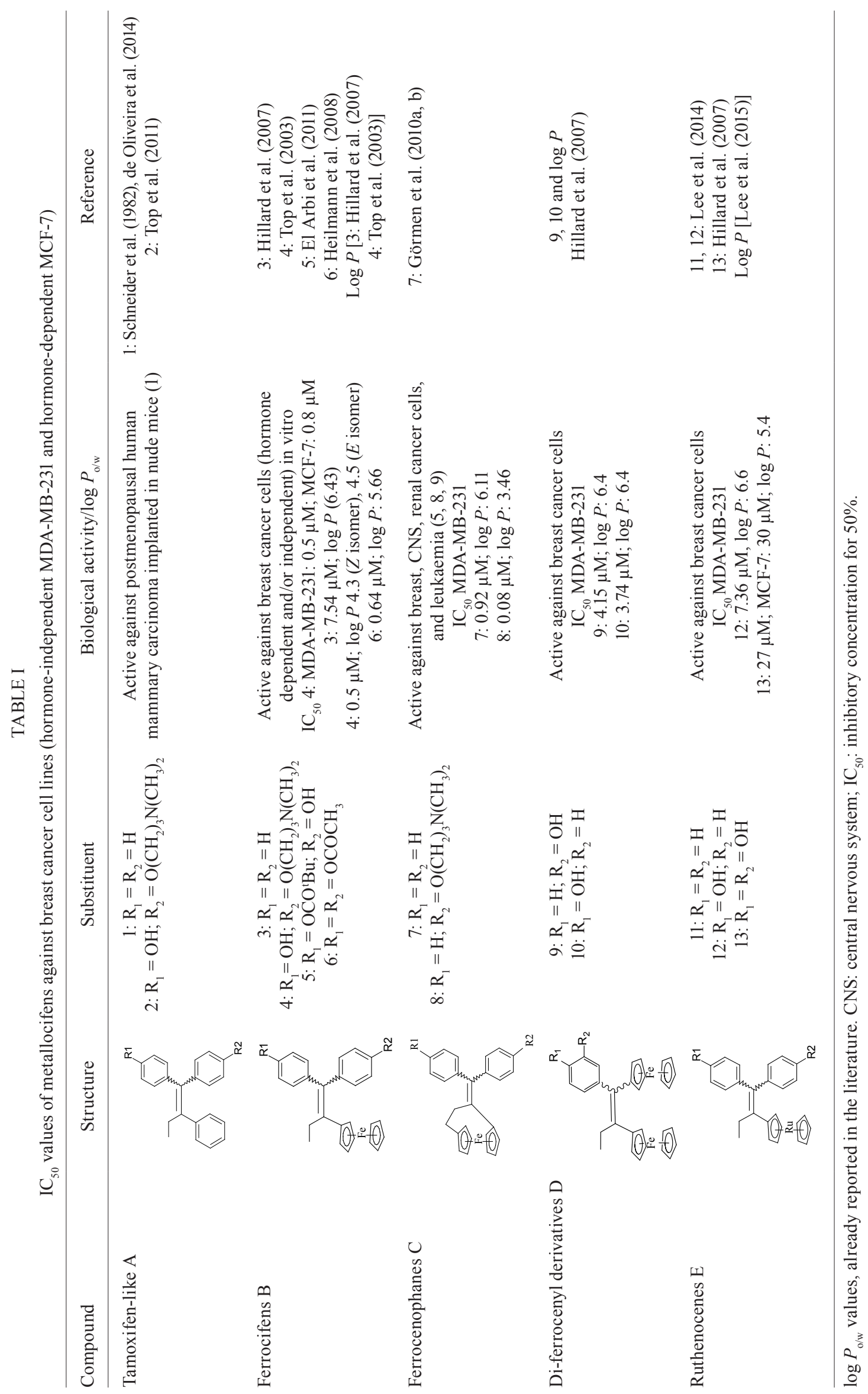



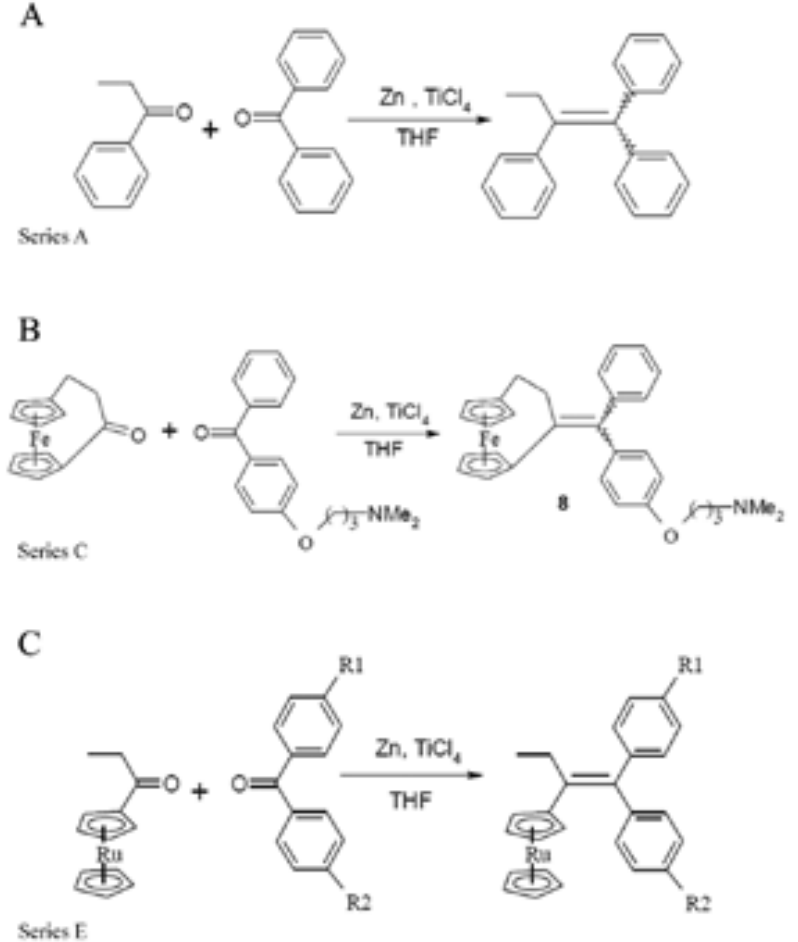

General scheme for the synthesis of compounds of series A (A), C (B), represented by the synthesis of the new compound 8 , and $\mathrm{E}(\mathrm{C})$. The same procedure was used for the other series with adequate precursors.

pounds in series $A(1,2)$, compounds having a ferrocenyl substituent in series B (3-6), a [3]ferrocenophane substituent $(7,8)$ in series $C$, two ferrocenyl groups $(9,10)$ in series D, and the ruthenocenes (11-13) in series E. Substitutions on the phenyl rings include hydroxyl, acetoxy, pivaloxy, and/or dimethylaminopropoxy groups.

$\log P$ values were determined for the first time in this paper, for compounds 6,7 , and 8 , being: 5.66, 6.11, and 3.46, respectively. All $\log P$ values are higher than 4 (except for compound 8, whose $\log P$ was 3.46 ), pointing to a lipophilic trend of the compounds. They can be ranked in a general fashion as follows (in decreasing order): diferrocenyl derivatives $>$ ruthenocenes $>$ tamoxifen-like derivatives $>$ ferrocifens, intermixed with the more lipophilic compound $3(\log P=6.43)$, and the more hydrophilic one, compound $8(\log P=3.46)$.

Most of the compounds were synthesised using a McMurry cross-coupling reaction $(1,3,7,8,9,10,11$, $12,13)$, or by functionalisation of a phenolic compound that were synthesised by this method $(2,4,5$, and 6 ) (Figure). Synthesis had been performed as previously reported for all compound classes summarised in Table I, except for compound 8, prepared using a McMurry reaction between the [3]ferrocenophan-1-one (Turbitt \& Watts 1972), and the 4-(3-dimethylaminopropoxy)benzophenone (Top et al. 2002), yielding 84\%.

Among the 13 tested compounds, six were active against $P$. falciparum CQ-resistant parasites based on the $\mathrm{IC}_{50}$ values (Table II). The most active compounds ( 2 and 4) showed $\mathrm{IC}_{50}$ below 6 , followed by compounds $8,12,13$, with $\mathrm{IC}_{50}$ values below $6 \mu \mathrm{M}$; compounds 3 and 11 were partially active $\left(\mathrm{IC}_{50}\right.$ values around $\left.16.6 \mu \mathrm{M}\right)$, and compounds 1 and 7 , with $\mathrm{IC}_{50}$ values above $60 \mu \mathrm{M}$, were considered inactive. These results show a special effect of the dimethylaminopropoxy chain, since the compounds bearing it $(2,4$, and 8$)$ ranked the first three places of activity.

Regarding the in vitro cytotoxicity tests against HepG2 cells, compounds 1, 7, and 11 exhibited MLD $_{50}$ value up to $3,516 \mu \mathrm{M}$, compounds 3,12 , and $13, \mathrm{MLD}_{50}$ values ranging from $479-266.2 \pm 3 \mu \mathrm{M}$, being considered nontoxic and moderately toxic, respectively. Remaining compounds $(2,4,5,6,8,9$, and 10) were considered toxic $\left(\mathrm{MLD}_{50}\right.$ values below $\left.100 \mu \mathrm{M}\right)$, especially compounds 2 and 4, with $\mathrm{MLD}_{50}$ values below $10 \mu \mathrm{M}$.

The compounds were ranked in relation to their SI (Table II, column 5) as: $11>12>13>1>7>3$. The other compounds exhibited low SI due to their high toxicity towards HepG2 cells.

\section{DISCUSSION}

Based on the present and published data (Soares et al. 2010), some interesting trends emerge. The presence of the dimethylaminopropoxy side-chain increases antiplasmodial activity, with $\mathrm{IC}_{50}$ values to around $2.2 \pm$ $0.05 \mu \mathrm{M}$ (for 2) and $0.7 \pm 0.1 \mu \mathrm{M}$ (for 4), and also their cytotoxicity, in comparison to 1 and 3 , respectively. In addition, we have shown that hydroxy moieties in para position, or biologically hydrolysable ester groups, as in 6 (Heilmann et al. 2008, Görmen et al. 2010a), also increase the cytotoxicity (Hillard et al. 2007). For this reason, compound 8 bearing only a dimethylaminopropoxy chain has lower cytotoxicity than 2 and 4 . Compounds having no substituent on the phenyl moieties had the lowest activities on HepG2 cells (1, 7, 3, and 11). The presence of the ferrocenyl group increases more than three times the antiplasmodial activity (1 vs. 3, and 2 vs. 4) (Table II). The toxicity also increased, thus diminishing the SI to undesirable values, as observed previously with cancer cell lines (de Oliveira et al. 2011). The compounds 4, 6, 9, and 10 become too toxic for P. falciparum. By contrast, ferrocenophane compounds 7 and 8 appear to be less toxic (SI $=41$ and 18 , respectively).

Interestingly, SI of ruthenocene compounds are better than that of ferrocene compounds. The $\mathrm{IC}_{50}$ value for 11 $(16.5 \pm 0.5 \mu \mathrm{M})$ is similar to that of $3(16.6 \pm 2.3 \mu \mathrm{M})$. By contrast, $\mathrm{MLD}_{50}$ values for these two compounds are very different, $2248 \pm 53 \mu \mathrm{M}$ vs. $479 \pm 89 \mu \mathrm{M}$. The presence of a phenol moiety in the ruthenocifen series increases not only the antiplasmodial, but also the cytotoxic activity (compound 12 and 13). Compound 11 appears to have the best profile, with SI $>100$. Low cytotoxicity of ruthenocenyl compounds, as compared to ferrocenyl compounds, was also observed for breast cancer cells (Gobec et al. 2014, Lee et al. 2015). Concerning different activities between ferrocenyl and ruthenocenyl compounds, it may well be due to their selective cytotoxicity. A recent work dealing with some of the molecules presented herein (Lee et al. 2015) attributed this differential cytotoxicity to the solubility and stability of the quinone-methide (QM) moieties formed after oxidation, as well as the rapidity of this process (ferrocenes form QM faster than ruthenocenes, whose phenoxy radicals are not turned into QM moieties 
TABLE II

Selectivity indexes (SI), the ratio between in vitro cytotoxicity [minimum lethal dose for $50 \%$ of the cells $\left(\mathrm{MLD}_{50}\right)$ ] and activity [inhibitory concentration for $50 \%\left(\mathrm{IC}_{50}\right), \mu \mathrm{M}$ ] against Plasmodium falciparum (Pf) of tamoxifen-like compounds and metallic derivatives

\begin{tabular}{|c|c|c|c|c|}
\hline $\begin{array}{l}\text { Compounds/ } \\
\text { series }\end{array}$ & $\begin{array}{l}\text { Structural } \\
\text { class }\end{array}$ & $\begin{array}{l}\text { MLD }_{50} \\
\text { HepG2 }^{a}\end{array}$ & $\begin{array}{l}\mathrm{IC}_{50} \\
\mathrm{Pf}\end{array}$ & $\begin{array}{c}\mathrm{SI} \\
\left(\mathrm{MLD}_{50} / \mathrm{IC}_{50}\right)\end{array}$ \\
\hline $1 / \mathrm{A}$ & Tamoxifen-like & $>3516$ & $83 \pm 5$ & 42 \\
\hline $2 / \mathrm{A}$ & & $<10$ & $2.2 \pm 0.05$ & Toxic \\
\hline $3 / \mathrm{B}$ & Ferrocifene & $479 \pm 89$ & $16.6 \pm 2.3$ & 29 \\
\hline 4/B & & $<7.7$ & $0.7 \pm 0.1$ & Toxic \\
\hline $5 / \mathrm{B}$ & & $<61$ & $23.6 \pm 9.8$ & Toxic \\
\hline $6 / \mathrm{B}$ & & $<61$ & $23.6 \pm 5.9$ & Toxic \\
\hline $7 / \mathrm{C}$ & [3]ferrocenophane & $>2562$ & $62.8 \pm 10.7$ & 41 \\
\hline $8 / \mathrm{C}$ & & $<63$ & $5.9 \pm 1.6$ & 18 \\
\hline 9/D & Di-ferrocenyl derivative & $<60$ & $27.1 \pm 23.2$ & Toxic \\
\hline $10 / \mathrm{D}$ & & $<60$ & $7.8 \pm 1.6$ & Toxic \\
\hline $11 / \mathrm{E}$ & Ruthenocene & $2248 \pm 53$ & $16.5 \pm 0.5$ & 136 \\
\hline $12 / \mathrm{E}$ & & $251 \pm 34$ & $4.7 \pm 1.3$ & 53 \\
\hline $13 / \mathrm{E}$ & & $266 \pm 3$ & $5.9 \pm 2.3$ & 45 \\
\hline CQ & Quinoline & $502 \pm 52$ & $0.1 \pm 0.02$ & 5,020 \\
\hline
\end{tabular}

$a$ : except for compounds 12 and 13, which were tested for cytotoxicity against normal monkey kidney cells using the neutral red method; CQ: chloroquine.

rapidly). The nature of the metallocene, which include redox properties and acidity of the phenolic proton of the radical cations also play a role. Ruthenocenic derivatives of peptide nucleic acids were also shown to be less toxic than the ferrocenic ones, which can be due to the higher chemical and oxidative stability of ruthenocene, in relation to ferrocene (Swarts et al. 2009).

Despite the use of few compounds for comparison in this work ( 1 vs. 3 vs. $11 ; 2$ vs. 4 ) and the absence of mechanistic studies, due to the extreme complexity of inherent possible events related to metal complexes (Gasser et al. 2011, Coogan et al. 2012), it is possible to suggest that the presence of redox-active metal centres increases the biological activity. Drug lipophilicity facilitates membrane permeability, providing accumulation of drug in the resistant parasite DV. This is possibly the cause for the increase of efficacy of organometallic compounds (Martínez et al. 2009, Rajapakse et al. 2009, Dubar et al. 2011, 2012, Glans et al. 2012).

In fact, $\log P$ values reported for the metallocenes presented herein suggest that these molecules can cross cell membranes readily. Within each series, there is no significant difference among the two metals $(\mathrm{Ru}, \mathrm{Fe})$ and the lipophilicity decreases in the order monophenol $>$ diphenol $>$ tamoxifen-like compounds. This is the trend expected for the addition of an hydroxyl group or an amino chain, the latter responsible for a stronger decrease (Lee et al. 2015).

Concerning specifically the structural classes of the present studied compounds toward cancer cells, electrochemical and biochemical studies (Pigeon et al. 2005, Hillard et al. 2007, Nguyen et al. 2007) pointed to the involve- ment of oxidative formation of cytotoxic quinone-type metabolites in the activity of many ferrocifens, inactivating proteins, or increasing oxidative stress in cells, leading to cells death (Nguyen et al. 2007, Hamels et al. 2009, Lee et al. 2014, 2015). Thus, the generation of reactive oxygen species may represent a mode of action against $P$. falciparum, as observed for other tamoxifen-like molecules bearing ferrocene moiety (Soares et al. 2010).

Some Ru complexes were shown to be kinase inhibitors (Debreczeni et al. 2006). They also inhibited thioredoxin reductase (Casini et al. 2008) which is an important system responsible for redox homeostasis in $P$. falciparum (Kanzok et al. 2000). Indeed, a recent study showed that ferrocenyl derivatives of tamoxifen, including some of those studied herein, targeted thioredoxin reductases of cancer cells (Citta et al. 2014).

Falcipain-2, a cystein protease involved in haemoglobin degradation in P. falciparum (Chugh et al. 2013), is also a likely target for compound 11 , since cystein proteases are amenable to be attacked by metals (Fricker 2010).

Other potential targets for ruthenocenic compounds include DNA and parasite proteins (Gambino \& Otero 2012), as shown for tumour cells (Brabec \& Nováková 2006, Casini et al. 2008). Indeed, Ru-arene complexes have been designed to interact with DNA by intercalation and methylation (Aird et al. 2002). Despite no DNA-interaction studies were performed with the ruthenocifens presented herein, a recent report (de Oliveira et al. 2014) proved, by performing differential pulse voltammetry and spectrophotometric analysis, the interaction of compound 3 with double-stranded DNA and single-stranded DNA. 
In conclusion, along with describing the synthesis of a new ferrocenophane, this work represents an additional evidence for the metal-complex approach enhancing the antiplasmodial activity, with emphasis to ruthenocifens, for the first time assayed against resistant $P$. falciparum parasites, showing the best therapeutic potential. Several possible modes of action are discussed, by comparison with the literature. A further structural optimisation is required in order to evaluate a larger library of such compounds, which is under way, together with investigation of the mechanism of action, based on the bioprobe potential use of Ru derivatives.

\section{ACKNOWLEDGEMENTS}

To Oswaldo Cruz Foundation, for providing facilities, and to Dr Elizabeth Hillard, for fruitful discussion.

\section{REFERENCES}

Adams M, Li Y, Khot H, de Kock C, Smith PJ, Land K, Chibale K, Smith GS 2013. The synthesis and antiparasitic activity of aryl and ferrocenyl-derived thiosemicarbazone ruthenium(II) - arene complexes. Dalton Trans 42: 4677-4685.

Aird RE, Cummings J, Ritchie AA, Muir M, Morris RE, Chen H, Sadler PJ, Jodrell DI 2002. In vitro and in vivo activity and cross resistance profiles of novel ruthenium(II) organometallic arene complexes in human ovarian cancer. Br J Cancer 86: 1652-1657.

Ashley EA, Dhorda M, Fairhurst RM, Amaratunga C, Lim P, Suon S, Sreng S, Anderson JM, Mao S, Sam B, Sopha C, Chuor CM, Nguon C, Sovannaroth S, Pukrittayakamee S, Jittamala P, Chotivanich K, Chutasmit K, Suchatsoonthorn C, Runcharoen R, Hien TT, Thuy-Nhien NT, Thanh NV, Phu NH, Htut Y, Han KT, Aye KH, Mokuolu OA, Olaosebikan RR, Folaranmi OO, Mayxay M, Khanthavong M, Hongvanthong B, Newton PN, Onyamboko MA, Fanello CI, Tshefu AK, Mishra N, Valecha N, Phyo AP, Nosten F, Yi P, Tripura R, Borrmann S, Bashraheil M, Peshu J, Faiz MA, Ghose A, Hossain MA, Samad R, Rahman MR, Hasan MM, Islam A, Miotto O, Amato R, MacInnis B, Stalker J, Kwiatkowski DP, Bozdech Z, Jeeyapant A, Cheah PY, Sakulthaew T, Chalk J, Intharabut B, Silamut K, Lee SJ, Vihokhern B, Kunasol C, Imwong M, Tarning J, Taylor WJ, Yeung S, Woodrow CJ, Flegg JA, Das D, Smith J, Venkatesan M, Plowe CV, Stepniewska K, Guerin PJ, Dondorp AM, Day NP, White NJ, Tracking Resistance to Artemisinin Collaboration 2014. Spread of artemisinin resistance in Plasmodium falciparum malaria. N Engl J Med 371: 411-423.

Barbosa MI, Corrêa RS, de Oliveira KM, Rodrigues C, Ellena J, Nascimento OR, Rocha VP, Nonato FR, Macedo TS, Barbosa-Filho JM, Soares MB, Batista AA 2014. Antiparasitic activities of novel ruthenium/lapachol complexes. J Inorg Biochem 136: 33-39.

Beagley P, Blackie MA, Chibale K, Clarkson C, Meijboom R, Moss JR, Smith PJ, Su H 2003. Synthesis and antiplasmodial activity in vitro of new ferrocene-chloroquine analogues. Dalton Trans 15: 3046-3051

Bézivin C, Tomasi S, Dévéhat Fl, Boustie J 2003. Cytotoxic activity of some lichen extracts on murine and human cancer cell lines. Phytomedicine 10: 499-503.

Biot C 2004. Ferroquine: a new weapon in the fight against malaria. Antiinfect Agents Med Chem 3: 135-147.

Biot C, Castro W, Botté CY, Navarro M 2012a. The therapeutic potential of metal-based antimalarial agents: implications for the mechanism of action. Dalton Trans 41: 6335-6349.

Biot C, Dubar F, Khalife J, Slomianny C 2012b. Opening up the advantages of the ruthenocenic bioprobes of ferroquine: distribu- tion and localization in Plasmodium falciparum-infected erythrocytes. Metallomics 4: 780-783.

Biot C, Pradines B, Sergeant MH, Gut J, Rosenthal PJ, Chibale K 2007. Design, synthesis, and antimalarial activity of structural chimeras of thiosemicarbazone and ferroquine analogues. Bioorg Med Chem Lett 17: 6434-6438.

Borenfreund E, Babich H, Martin-Alguacil N 1987. Comparisons of two in vitro cytotoxicity assays: the neutral red (NR) and tetrazolium MTT tests. Toxicol In Vitro 2: 1-6.

Brabec V, Nováková O 2006. DNA binding mode of ruthenium complexes and relationship to tumor cell toxicity. Drug Resist Updat 9: $111-122$.

Casini A, Gabbiani C, Sorrentino F, Rigobello MP, Bindoli A, Geldbach TJ, Marrone A, Re N, Hartinger CG, Dyson PJ, Messori L 2008. Emerging protein targets for anticancer metallodrugs: inhibition of thioredoxin reductase and cathepsin B by antitumor ruthenium(II)-arene compounds. J Med Chem 51: 6773-6781.

Cázares-Marinero JJ, Top S, Vessières A, Jaouen G 2014. Synthesis and antiproliferative activity of hydroxyferrocifen hybrids against triple-negative breast cancer cells. Dalton Trans 43: 817-830.

Chellan P, Land KM, Shokar A, Au A, An SH, Taylor D, Smith PJ, Chibale K, Smith GS 2013. Di-and trinuclear ruthenium, rhodium, and iridium-functionalized pyridyl aromatic ethers: a new class of antiparasitic agents. Organometallics 32: 4793-4804.

Chellan P, Land KM, Shokar A, Au A, An SH, Taylor D, Smith PJ, Riedel T, Dyson PJ, Chibale K, Smith GS 2014. Synthesis and evaluation of new polynuclear organometallic $\mathrm{Ru}(\mathrm{II}), \mathrm{Rh}(\mathrm{III})$ and $\operatorname{Ir}(\mathrm{III})$ pyridyl ester complexes as in vitro antiparasitic and antitumor agents. Dalton Trans 43: 513-526.

Chugh M, Sundararaman V, Kumar S, Reddy VS, Siddiqui WA, Stuart KD, Malhotra P 2013. Protein complex directs hemoglobin-to-hemozoin formation in Plasmodium falciparum. Proc Natl Acad Sci USA 110: 5392-5397.

Citta A, Folda A, Bindoli A, Pigeon P, Top S, Vessières A, Salmain M, Jaouen G, Rigobello MP 2014. Evidence for targeting thioredoxin reductases with ferrocenyl quinone methides. A possible molecular basis for the antiproliferative effect of hydroxyferrocifens on cancer cells. J Med Chem 57: 8849-8859.

Coogan MP, Dyson PJ, Bochmann M 2012. Introduction to the organometallics in biology and medicine issue. Organometallics 31 : 5671-5672.

de Madureira MC, Martins AP, Gomes M, Paiva J, Cunha AP, Rosário V 2002. Antimalarial activity of medicinal plants used in traditional medicine in S. Tome and Principe islands. J Ethnopharmacol 81: 23-29.

de Oliveira AC, da Silva EG, Rocha DD, Hillard EA, Pigeon P, Jaouen G, Rodrigues FA, de Abreu FC, Ferreira FR, Goulart MO, Costa-Lotufo LV 2014. Molecular mechanism of action of 2-ferrocenyl-1,1-diphenylbut-1-ene on HL-60 leukemia cells. ChemMedChem 11: 2580-2586.

de Oliveira AC, Hillard EA, Pigeon P, Rocha DD, Rodrigues FA, Montenegro RC, Costa-Lotufo LV, Goulart MO, Jaouen G 2011. Biological evaluation of twenty-eight ferrocenyl tetrasubstituted olefins: cancer cell growth inhibition, ROS production and hemolytic activity. Eur J Med Chem 46: 3778-3787.

Debreczeni JE, Bullock AN, Atilla GE, Williams DS, Bregman H, Knapp S, Meggers E 2006. Ruthenium half-sandwich complexes bound to protein kinase pim-1. Angew Chem Int Ed Engl 45: 1580-1585.

Denizot F, Lang R 1986. Rapid colorimetric assay for cell growth and survival. Modifications to the tetrazolium dye procedure giving improved sensitivity and reliability. J Immunol Methods 89: 271-277. 
Dubar F, Bohic S, Slomianny C, Morin JC, Thomas P, Kalamou H, Guérardel Y, Cloetens P, Khalife J, Biot C 2012. In situ nanochemical imaging of label-free drugs: a case study of antimalarials in Plasmodium falciparum-infected erythrocytes. Chem Commun 48: 910-912.

Dubar F, Egan TJ, Pradines B, Kuter D, Ncokazi KK, Forge D, Paul JF, Pierrot C, Kalamou H, Khalife J, Buisine E, Rogier C, Vezin H, Forfar I, Slomianny C, Trivelli X, Kapishnikov S, Leiserowitz L, Dive D, Biot C 2011. The antimalarial ferroquine: role of the metal and intramolecular hydrogen bond in activity and resistance. ACS Chem Biol 6: 275-287.

El Arbi M, Pigeon P, Top S, Rhouma A, Aifa S, Rebai A, Vessières A, Plamont MA, Jaouen G 2011. Evaluation of bactericidal and fungicidal activity of ferrocenyl or phenyl derivatives in the diphenyl butene series. J Organomet Chem 69: 1038-1048.

Fricker SP 2010. Cysteine proteases as targets for metal-based drugs. Metallomics 2: 366-377.

Gambino D, Otero L 2012. Perspectives on what ruthenium-based compounds could offer in the development of potential antiparasitic drugs. Inorg Chim Acta 393: 103-114.

Gasser G, Ott I, Metzler-Nolte N 2011. Organometallic anticancer compounds. J Med Chem 54: 3-25.

Glans L, Ehnbom A, de Kock C, Martínez A, Estrada J, Smith PJ, Haukka M, Sánchez-Delgado RA, Nordlander E 2012. Ruthenium(II) arene complexes with chelating chloroquine analogue ligands: synthesis, characterization and in vitro antimalarial activity. Dalton Trans 41: 2764-2773.

Gobec M, Kljun J, Sosič I, Mlinarič-Raščan I, Uršič M, Gobec S, Turel I 2014. Structural characterization and biological evaluation of a clioquinol-ruthenium complex with copper-independent antileukaemic activity. Dalton Trans 43: 9045-9051.

Görmen M, Pigeon P, Top S, Hillard EA, Huché M, Hartinger CG, de Montigny F, Plamont MA, Vessières A, Jaouen G 2010a. Synthesis, cytotoxicity, and COMPARE analysis of ferrocene and [3] ferrocenophane tetrasubstituted olefin derivatives against human cancer cells. ChemMedChem 5: 2039-2050.

Görmen M, Pigeon P, Top S, Vessières A, Plamont M, Hillard EA, Jaouen G 2010b. Facile synthesis and strong antiproliferative activity of disubstituted diphenylmethylidenyl-[3]ferrocenophanes on breast and prostate cancer cell lines. MedChem Cоттии 1: 149-151.

Graf PC, Durand S, Alvarez AC, Montalvan C, Montoya MG, Green MD, Santolalla ML, Salas C, Lucas C, Bacon DJ, Fryauff DJ 2012. Failure of supervised chloroquine and primaquine regimen for the treatment of Plasmodium vivax in the Peruvian Amazon. Malar Res Treat 2012: 5 pp.

Hamels D, Dansette PM, Hillard EA, Top S, Vessieres A, Herson P, Jaouen G, Mansuy D 2009. Ferrocenyl quinone methides as strong antiproliferative agents: formation by metabolic and chemical oxidation of ferrocenyl phenols. Angew Chem Int Ed Engl 48: 9124-9126.

Heilmann JB, Hillard EA, Plamont MA, Pigeon P, Bolte M, Jaouen G, Vessières AJ 2008. Ferrocenyl compounds possessing protected phenol and thiophenol groups: synthesis, X-ray structure, and in vitro biological effects against breast cancer. J Organomet Chem 693: 1716-1722.

Held J, Jeyaraj S, Kreidenweiss A 2015a. Antimalarial compounds in Phase II clinical development. Expert Opin Investig Drugs 24: 363-382

Held J, Supan C, Salazar CLO, Tinto H, Bonkian LN, Nahum A, Moulero B, Sié A, Coulibaly B, Sirima SB, Siribie M, Otsyula N, Otieno L, Abdallah AM, Kimutai R, Bouyou-Akotet M, Kombila
M, Koiwai K, Cantalloube C, Din-Bell C, Djeriou E, Waitumbi J, Mordmüller B, Ter-Minassian D, Lell B, Kremsner PG 2015b. Ferroquine and artesunate in African adults and children with Plasmodium falciparum malaria: a Phase 2, multicentre, randomised, double-blind, dose-ranging, non-inferiority study. Lancet Infect Dis doi: 10.1016/S1473-3099(15)00079-1.

Hillard EA, Pigeon P, Vessières A, Amatore C, Jaouen G 2007. The influence of phenolic hydroxy substitution on the electron transfer and anti-cancer properties of compounds based on the 2-ferrocenyl-1-phenyl-but-1-ene motif. Dalton Trans 43: 5073-5081.

Kanzok SM, Schirmer RH, Turbachova I, Iozef R, Becker K 2000. The thioredoxin system of the malaria parasite Plasmodium falciparum glutathione reduction revisited. J Biol Chem 275: 40180-40186.

Lambros C, Vanderberg JP 1979. Sychronization of Plasmodium falciparum erythrocytic stages in culture. J Parasitol 65: 418-420.

Lee HZS, Buriez O, Chau F, Labbé E, Ganguly R, Amatore C, Jaouen G, Vassières A, Leong WK, Top S 2015. Synthesis, characterization, and biological properties of osmium-based tamoxifen derivatives-comparison with their homologues in the iron and ruthenium series. Eur J Inorg Chem 25: 4217-4226.

Lee HZS, Buriez O, Labbé E, Top S, Pigeon P, Jaouen G, Amatore C, Leong WK 2014. Oxidative sequence of a ruthenocene-based anticancer drug candidate in a basic environment. Organometallics 33: 4940-4946.

Marques MM, Costa MR, Santana Filho FS, Vieira JL, Nascimento MT, Brasil LW, Nogueira F, Silveira H, Reyes-Lecca RC, Monteiro WM, Lacerda MV, Alecrim MG 2014. Plasmodium vivax chloroquine resistance and anemia in the western Brazilian Amazon. Antimicrob Agents Chemother 58: 342-347.

Martínez A, Carreon T, Iniguez E, Anzellotti A, Sánchez A, Tyan M, Sattler A, Herrera L, Maldonado RA, Sánchez-Delgado RA 2012. Searching for new chemotherapies for tropical diseases: ruthenium-clotrimazole complexes display high in vitro activity against Leishmania major and Trypanosoma cruzi and low toxicity toward normal mammalian cells. J Med Chem 55: 3867-3877.

Martínez A, Rajapakse CS, Jalloh D, Dautriche C, Sánchez-Delgado RA 2009. The antimalarial activity of Ru-chloroquine complexes against resistant Plasmodium falciparum is related to lipophilicity, basicity, and heme aggregation inhibition ability near water $/ \mathrm{n}$ octanol interfaces. J Biol Inorg Chem 14: 863-871.

Minick DJ, Frenz JH, Patrick MA, Brent DA 1988. A comprehensive method for determining hydrophobicity constants by reversedphase high-performance liquid chromatography. J Med Chem 31: 1923-1933.

Miotto O, Almagro-Garcia J, Manske M, Macinnis B, Campino S, Rockett KA, Amaratunga C, Lim P, Suon S, Sreng S, Anderson JM, Duong S, Nguon C, Chuor CM, Saunders D, Se Y, Lon C, Fukuda MM, Amenga-Etego L, Hodgson AV, Asoala V, Imwong M, Takala-Harrison S, Nosten F, Su XZ, Ringwald P, Ariey F, Dolecek C, Hien TT, Boni MF, Thai CQ, Amambua-Ngwa A, Conway DJ, Djimdé AA, Doumbo OK, Zongo I, Ouedraogo JB, Alcock D, Drury E, Auburn S, Koch O, Sanders M, Hubbart C, Maslen G, Ruano-Rubio V, Jyothi D, Miles A, O’Brien J, Gamble C, Oyola SO, Rayner JC, Newbold CI, Berriman M, Spencer CC, McVean G, Day NP, White NJ, Bethell D, Dondorp AM, Plowe CV, Fairhurst RM, Kwiatkowski DP 2013. Multiple populations of artemisinin-resistant Plasmodium falciparum in Cambodia. Nat Genet 45: 648-655.

Nguyen A, Vessières A, Hillard EA, Top S, Pigeon P, Jaouen G 2007. Ferrocifens and ferrocifenols as new potential weapons against breast cancer. Chimia 61: 716-724.

Noedl H, Wongsrichanalai C, Miller R, Myint K, Looareesuwan S, Sukthana Y, Wongchotigul V, Kollaritsch H, Wiedermann G, 
Wernsdorfer W 2002. Plasmodium falciparum: effect of antimalarial drugs on the production and secretion characteristics of histidine-rich protein II. Exp Parasitol 102: 157-163.

Oduola AM, Weatherly NF, Bowdre JH, Desjardins RE 1988. Plasmodium falciparum: induction of resistance to mefloquine in cloned strains by continuous drug exposure in vitro. Exp Parasitol 67: 354-360.

Pigeon P, Top S, Vessières A, Huché M, Hillard EA, Salomon E, Jaouen G 2005. Selective estrogen receptor modulators in the ruthenocene series. Synthesis and biological behaviour. J Med Chem 48: 2814-2821.

Pizarro AM, Habtemariam A, Sadler PJ 2010. Activation mechanisms for organometallic anticancer complexes. Top Organomet Chem 32: $21-56$.

Pomper MG, Vanbrocklin H, Thieme AM, Thomas RD, Kiesewetter DO, Carlson KE, Mathias CJ, Welch MJ, Katzenellenbogen JA 1990. 11.beta.-methoxy-, 11.beta.-ethyl, and 17.alpha.-ethynylsubstituted 16.alpha.-fluoroestradiols: receptor-based imaging agents with enhanced uptake efficiency and selectivity. $J$ Med Chem 33: 3143-3155.

Rajapakse CS, Martínez A, Naoulou B, Jarzecki AA, Suárez L, Deregnaucourt C, Sinou V, Schrével J, Musi E, Ambrosini G, Schwartz GK, Sánchez-Delgado RA 2009. Synthesis, characterization, and in vitro antimalarial and antitumor activity of new ruthenium(II) complexes of chloroquine. Inorg Chem 48: 1122-1131.

Rieckmann K, Campbell G, Sax L, Mrema J 1978. Drug sensitivity of Plasmodium falciparum. An in vitro microtechnique. Lancet 1: $22-23$.

Schneider MR, von Angerer E, Schönenberger H, Michel RT, Fortmeyer HP 1982. 1,1,2-triphenylbut-1-enes: relationship between structure, estradiol receptor affinity, and mammary tumor inhibiting properties. J Med Chem 25: 1070-1077.

Soares MBP, Costa JFO, de Sa MS, dos Santos RR, Pigeon P, Jaouen G, Sant'ana AEG, Goulart MOF, Hillard EA 2010. Antiparasitic and immunomodulatory activities of 1,1-bis(4-hydroxyphenyl)2-phenyl-but-1-ene and its protected and free 2-ferrocenyl derivatives. Drug Develop Res 71: 69-75.
Swarts JC, Nafady A, Roudebush JH, Trupia S, Geiger WE 2009. Oneelectron oxidation of ruthenocene: reactions of the ruthenocenium ion in gentle electrolyte media. Inorg Chem 48: 2156-2165.

Tan YL, Pigeon P, Top S, Labbé E, Buriez O, Hillard EA, Vessières A, Amatore C, Leong WK, Jaouen G 2012. Ferrocenyl catechols: synthesis, oxidation chemistry and anti-proliferative effects on MDA-MB-231 breast cancer cells. Dalton Trans 41: 7537-7549.

Top S, Efremenko I, Rager MN, Vessières A, Yaswen P, Jaouen G, Fish RH 2011. Synthetic and mechanistic pathways of cis and trans-hydroxytamoxifen drug derivatives reacting with $\mathrm{Cp} * \mathrm{Rh}$ complexes that involve $\eta^{1}-\mathrm{N}, \eta^{2}-\mathrm{N}, \mathrm{O}, \eta^{1}-\mathrm{O}$, and $\eta^{6}$ bonding modes, via a novel $\mathrm{N}-\pi$ rearrangement; relative binding affinities and computer docking studies of cis and trans- $\eta 6-\mathrm{Cp}^{*} \mathrm{Rh}-\mathrm{hydroxytamoxifen} \mathrm{com-}$ plexes at the estrogen, ER $\alpha$ and ER $\beta$ receptors, and growth inhibition to breast cancer cells. Inorg Chem 50: 271-284.

Top S, Kaloun EB, Vessières A, Laios I, Leclercq G, Jaouen G 2002. The first titanocenyl dichloride moiety vectorised by a selective estrogen receptor modulator (SERM). Synthesis and preliminary bio-chemical behaviour. J Organomet Chem 643-644: 350-356.

Top S, Vessières A, Leclercq G, Quivy J, Tang J, Vaissermann J, Huché M, Jaouen G 2003. Synthesis, biochemical properties and molecular modeling studies of organometallic specific estrogen receptor modulators (SERMs), the ferrocifens and hydroxyferrocifens: evidence for an antiproliferative effect of hydroxyferrocifens on both hormone-dependent and hormone-independent breast cancer cell lines. Chemistry 9: 5223-5236.

Trager W, Jensen JB 1976. Human malaria parasites in continuous culture. Science 193: 673-675.

Turbitt TD, Watts WE 1972. Bridged ferrocenes. XII. Synthesis of [3] ferrocenophan-1-one from ferrocene by a novel one-step annelation reaction. J Organomet Chem 46: 109-117.

Wenzel M, Patra M, Senges CHR, Ott I, Stepanek JJ, Pinto A, Prochnow P, Vuong C, Langklotz S, Metzler-Nolte N, Bandow JE 2013. Analysis of the mechanism of action of potent antibacterial heterotri-organometallic compounds: a structurally new class of antibiotics. ACS Chem Biol 8: 1442-1450.

WHO - World Health Organization 2014. World malaria report 2014. Available from: who.int/malaria/publications/world_malaria_report 2014/en/. 